RESEARCH PAPERS

\title{
CEO AND BUSINESSES ARE LOSING TRUST: COMPARISON OF EU, USA, CZECH AND SLOVAK REPUBLIC
}

\author{
Kasl Kollmannová, D.
}

This article presents an in-depth study based on open-source data analysis (Edelman Trust Barometer and European Communication Monitor) concerning the general loss of trust, which both commercial companies, governments and, on a minor scale, also NGOs have been experiencing since the Global Financial Crisis in 2008. Trust is an essential line of corporate communications, public relations and reputation management of companies and it is personalized by the CEOs and top management. According to the data, the trust of CEOs saw the biggest decline in the U.S. while in Slovakia the trust is still quite high; on the contrary, in the E.U. in general, the level of trust of CEOs reached a historical minimum of $30 \%$. The overall shift from trusting the traditional authorities, such as government, CEOs and official representatives to academics, stakeholders, employees and general "vox populi" can be seen globally. The aim of this article is to define trust and the social and communications context of building trust as a key factor in a company's reputation. Finally, clear managerial implications on reputation management focusing on Czech and Slovak CEOs and businesses will be given.

JEL Classification: M30

\section{Introduction}

The Global Financial Crisis, which peaked in 2008, was named by many as the worst economic crisis since the Great Depression in 1930's. ${ }^{1}$ It had lead into a global recession, which affected also the European markets, namely Ireland, Portugal, Spain and Greece. Yet the financial crisis is not only about the falling prices, collapse of banks and financial institutions, or stock exchange prices. It has affected people's lives, causing the high rise of unemployment, social protests and demonstrations, rising prices of consumer goods and almost a run on the banks in Greece where people started withdrawing money for fear of a bank's collapse (Tseng, 2012). Generally speaking, people started losing

1 The Global Financial Crisis (2007-2012) started with the U.S. housing bubble, which was followed by banking problems, an impact on the stock markets and global business. Among the critics, see economist Nouriel Roubini Roubini (Roubini, 2012), or Nobel Prize Winner Joseph Stiglitz (Stiglitz, 2012) or Paul Krugman (Krugman, 2009). trust of the governments which caused rising public debt and of the financial institutions which performed moral hazard operations leading to financial problems yet rewarded their management with high bonuses.

\section{Trust in business and governments is declining globally}

This article presents an in-depth study based on two open-source data analyses (Edelman Trust Barometer and European Communication Monitor) to examine the trend of decreasing trust in CEOs and businesses and to examine the implications for change in communication strategy and reputation management of CEOs and companies. According to Edelman Global Trust Barometer, a study which focuses on tracking the opinion changes of informed public in 25 countries, ${ }^{2}$ general

2 The survey covers $30,000+$ respondents in 25 countries, 1000 general respondents per country aged $18+$, oversample of informed publics aged 25-64, college-educated in top $25 \%$ of household income per age group (Edelman, 2012). 
distrust is growing. Nearly twice as many countries are now skeptics - only a few countries are holding a neutral status. Among the "trusters" topping the list are China, the United Arab Emirates and Singapore. Certainly we have to keep in mind the intercultural differences when asking about specific topics in culturally and politically varied regions, such as the U.S., China and Arabic countries, and ask though, how often the answer is mere a proclamation rather than a personal opinion.

The Netherlands and Canada, Italy, Argentina, Australia and Brazil, are keeping a neutral or higher than average trust status. Together with India among the top trusters, we can say that in the BRIC countries (Brazil, Russia, India, China), we can still see a positive outlook with the exclusion of Russia, which finishes the list as the least trusting country (32 out of 100, far below the global status of 51, see Graph 1 below).

\section{Defining "trust" in business and society}

If we look at the concept of trust, it is an essential word in business, and it has been there especially since the rise of the modern banking and loan system, rise of stock markets and change of symbolic value, represented by monetary systems (Ferguson, 2009). However, the concept of what really "trust" is remains unclear - rising from a philosophical background, epistemology, philosophy of mind, and value theory. When answering the question "When is trust warranted?" there is not one answer for all. "For example, in responding to the question, one might appeal to the nature of trust and trustworthiness, and consider whether the attitude of the proposed trustor could support trust, and whether the qualities of the proposed trustee indicate trustworthiness. But to decide such matters, one first has to settle the difficult issue of whether, to be trustworthy, a person must have a particular kind of motive for acting" (McLeod, 2011).

Niklas Luhmann (Luhmann, 1979) has extensively studied the role of trust in system theory, resulting in a two-volume publication of Trust and Power, which became influential for later generations of thinkers. Francis Fukuyama defined trust as "the expectation that arises within a community of regular, honest, and cooperative behavior, based on commonly shared norms, on the part of other members of that community" (Fukuyama, 1995).

\section{Graph 1 Global growth of distrust}

Distrust is growing; nearly twice as many countries are now skeptics

Fewer now in neutral zone

2011

\begin{tabular}{|c|c|c|c|c|}
\hline GLOBAL & 55 & GLOBAL & 51 & \\
\hline Brazil & 80 & China & 76 & \\
\hline UAE & 78 & $\overline{\text { UAE }}$ & 68 & \\
\hline Ind onesia & 74 & Sing apore & 67 & \\
\hline China & 73 & India & 65 & TRUS TERS \\
\hline Netherlands & 73 & Indonesia & 63 & \\
\hline Mexico & 69 & Mexico & 63 & \\
\hline Singap ore & 67 & Netherlands & 61 & \\
\hline Argentina & 62 & Canada & 58 & \\
\hline India & 56 & Italy & 56 & \\
\hline Italy & 56 & Arg ent ina & 54 & NEUTRAL \\
\hline Ca nada & 55 & Australia & 53 & \\
\hline South Korea & 53 & Brazil & 51 & \\
\hline Sweden & 52 & Sweden & 49 & \\
\hline Japan & & US. & 49 & \\
\hline Australia & 51 & SouthKorea & 44 & \\
\hline Spain & 51 & Poland & 44 & \\
\hline France & 50 & U.K. & 41 & \\
\hline Poland & 49 & Ireland & 41 & DIST RUSTERS \\
\hline Germany & 44 & France & 40 & \\
\hline U.S. & 42 & Germany & 39 & \\
\hline U.K. & 40 & Spain & 37 & \\
\hline Russia & 40 & Japan & 34 & \\
\hline Ireland & 39 & Russia & 32 & \\
\hline
\end{tabular}

Source: Edelman, 2012 


\section{Graph 2 Gaining trust as an essential goal of communication and PR managers in European countries}

Gaining stakeholders' trust as a goal of communication management in various types of organizations

\begin{tabular}{|c|c|c|c|c|}
\hline & $\begin{array}{l}\text { Joint stock } \\
\text { companies }\end{array}$ & $\begin{array}{c}\text { Private } \\
\text { companies }\end{array}$ & $\begin{array}{l}\text { Governemntal } \\
\text { organizations }\end{array}$ & $\begin{array}{c}\text { Non-profit } \\
\text { organizations }\end{array}$ \\
\hline $\begin{array}{l}\text { Enhance trust in leaders } \\
\text { of my organisation }\end{array}$ & $84.3 \%$ & $74.2 \%$ & $75.8 \%$ & $77.7 \%$ \\
\hline $\begin{array}{l}\text { Enhance trust in my } \\
\text { organisation and/or } \\
\text { its brand }\end{array}$ & $94.9 \%$ & $92.3 \%$ & $88.9 \%$ & $95.3 \%$ \\
\hline $\begin{array}{l}\text { Enhance trust in our } \\
\text { markets or business } \\
\text { at large }\end{array}$ & $82.0 \%$ & $78.8 \%$ & $62.8 \%$ & $78.1 \%$ \\
\hline
\end{tabular}

Source: Zerfass et al., $2011^{3}$

Despite that fact the concept of trust is divided into many sub-themes, such as the (1) politlogical concept of public trust, deriving the legitimacy of government based on democratic principles in which trust plays a crucial role (also governmental trust, see Hardin 2002), (2) concept of institutional trust (e.g. trust in institutions, see Potter, 2002; Govier, 1997), and (3) psychological concept of self-trust (see e.g. Lehrer, 1997). In the economic point of view, James (James, 2002) states: "In the language of economics, trust can be viewed as an expectation, and it pertains to circumstances in which agents take risky actions in environments characterized by uncertainty or informational incompleteness. To say ,A trusts $\mathrm{B}^{\prime}$ means that A expects B will not exploit a vulnerability A has created for himself by taking the action" (James, 2002, p. 291). All the above mentioned concepts of trust are based on and derived from the basic, interpersonal concept of trust, whether it is represented by institutions, governments or individuals. In today's information society, our day-to-day experience is based on the trust of several information sources, which are often distant and mediated (Virilio, 2001). In Public Relations and Communication Management, building trust in a company, its representatives and products/services plays a central role, according to the biggest pan-European survey conducted in 2011 (Zerfass et al. 2011). Building trust of its own organization is almost equally important for joint stock companies as it is for NGOs (see Graph 2). Gunter Bentele and others (Bentele - Seidenglanz 2005) explore the problems of gaining the trust of companies, especially when it comes to CSR of generally big companies, such as the energetic company RWE and its "green marketing" (Bentele - Nothhaft 2011).

\section{The position of trust in communication management}

For governmental organizations, only $62.8 \%$ of communication managers believe it's important to build trust into the whole governmental body, they are representatives of. In contrary, joint-stock company communication and PR representatives do believe more $(82 \%)$ that general trust of the system is a key value. If general trust in the stock exchange drops, the immediate effects on the economy are obvious and may lead into economic crisis as in 1929 or 2008. Thus also governments are usually less trusted than business companies in general (see Graph 2 above), because also governmental representatives do not enhance the trust of governmental bodies as such, but more likely of their own personality, party, department or fraction.

3 Source: Zerfass, A., Verhoeven, P., Tench, R., Moreno, A., \& Verčič, D. (2011): European Communication Monitor 2011. Empirical Insights into Strategic Communication in Europe. Results of an Empirical Survey in 43 Countries (Chart Version). Brussels: EACD, EUPRERA (available at: www.communicationmonitor.eu) $\mathrm{n}=1,450$ PR professionals in communication departments; Q 9: Communication management may strive to gain stakeholders f trust in people, organizations, and societal systems as a whole. How relevant are each of the following goals in your daily work? Scale1 (= not relevant) .5 (= very relevant), considered scale points: 4-5 / Q 20. No significant differences between the different types of organisations (chi-square test, p.0.05). 
If we look at the question, "Who do you trust?", then apart from our close significant others, relatives, friends or colleagues, we have to think about opinion leaders, who are mostly distant and mediated from us. These people are our information sources, no matter if they appear on $\mathrm{TV}$, in newspapers or radio news, but also through the social media such as Twitter, Facebook, LinkedIn, etc. Traditionally, we tend to believe people with high education, high moral status and longer life experience - such as doctors, university professors and scientists.

\section{Trustworthiness of information sources:}

\section{comparison of EU, USA, Czech and Slovak Republic}

However, trust can vary from country to country depending on the political situation, economic factors and most importantly on cultural values in each society. We use Hofstedes's cultural dimensions, such as power distance index, which measures individual differences in each country's position towards the inequality of power in society (Hofstede 2001). Based on the Edelman Trust Barometer localized survey, which was focusing on the informed publics in each region (see Graph 3) , we $^{4}$ can see several trends across the nations: academics or experts, followed by technical scientists or experts are the most trusted persons globally. In the Czech and Slovak Republics, we can see a higher inclination to believe the traditional authorities, such as experts, scientists, financial analysts and CEOs, than in the U.S. or E.U. On the contrary, in the Czech and Slovak Republics, the trust of NGOs and "people like me" as well as regular employees is generally lower. In Slovakia, only $44 \%$ believe what their peers are saying, opposed to the U.S., where the "vox populi" rises up to $65 \%$.

In one aspect, all the mentioned countries are allies: the distrust of government officials or bureaucrats has fallen down to less than one third, between $29-31 \%$. In the European countries, apart from Czech and Slovak Republic, there is also a great mistrust of CEOs -the same as government officials, e.g. $30 \%$. We have to ask then: are the CEO's performing so badly, or is it a general mistrust of leading authorities, which is causing the great fall of CEO credibility?

\section{2: We don't believe the CEO anymore}

As stated above, the matter of trust, either institutional, governmental or public, can be always cited as example of interpersonal trust: "I either trust the person, or not". The companies are personalized by their leaders,

\section{Graph 3 Trustworthiness of information sources: Comparison between U.S., E.U., Czech and Slovak Republic ${ }^{5}$}

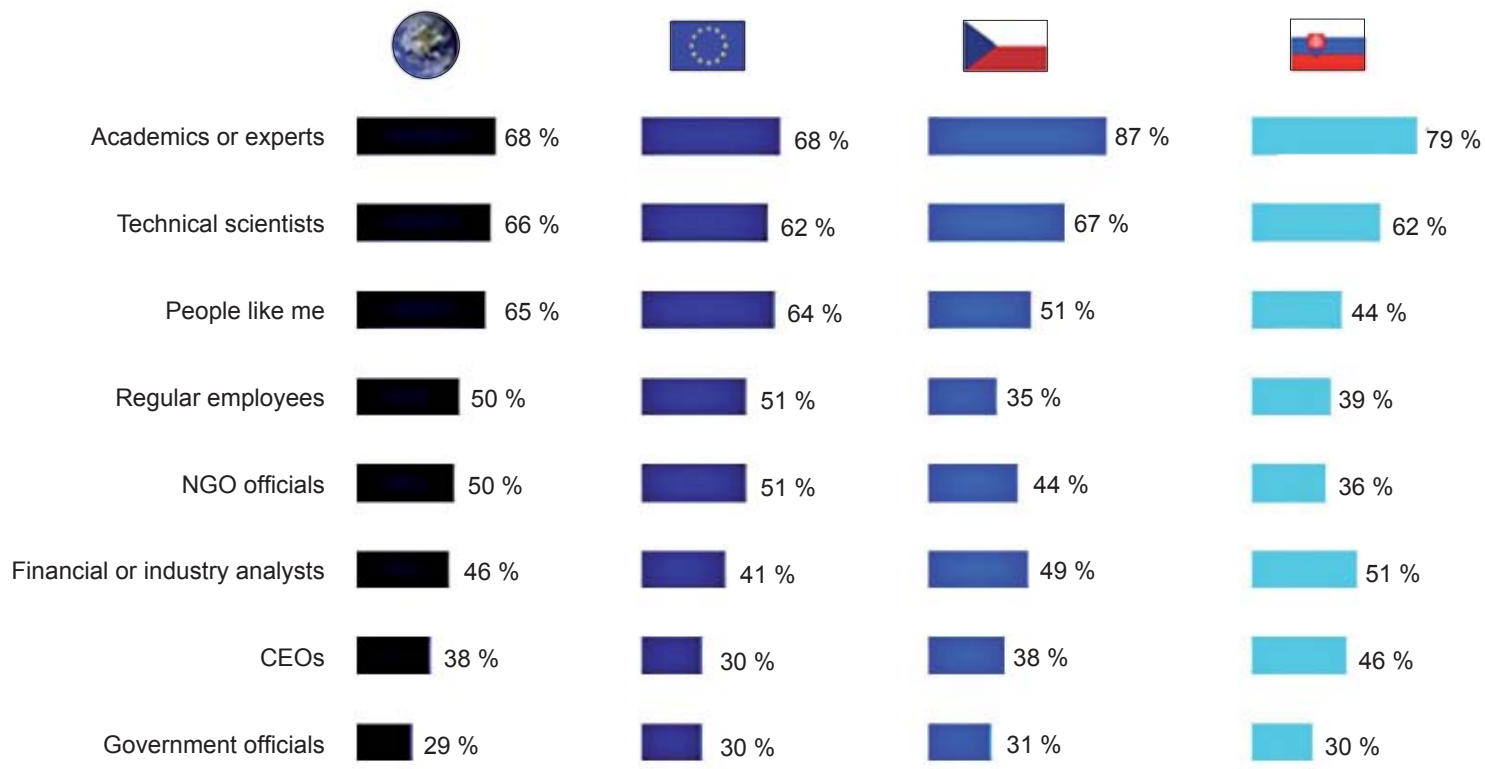

Source: AMI Communications, 2012

4 The data from the Czech and Slovak Republics were collected for the first time in this international survey. The data from the Czech Republic was collected by Stem/Mark in April 2012.
5 Source: Edelman Trust Barometer: Czech, Slovak and Bulgarian Data. In: AMI Communications. Češi jsou národem nevěřících Tomášů. Press release. May 14th, 2012. 
Graph 4 The fall of CEO credibility globally in $2012^{8}$ (credible spokespeople)

Credibility of CEOs and government officials plummet

Peers and regular employees see dramatic rise

\section{1}

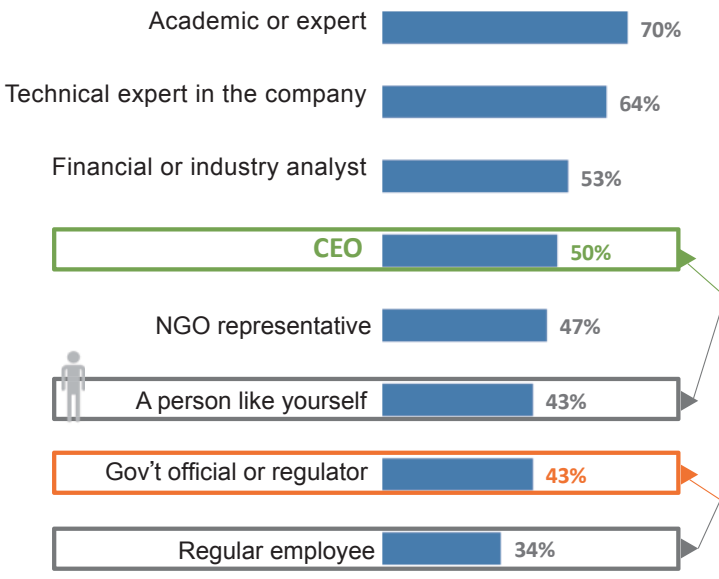

Source: Edelman, 2012

CEOs or other top managers, representing the company; people such as ministers and presidents are the personalized representation of the government.

The trust of the CEO and leaders of an institution are playing an important role in public relations and communication management (see Graph 2 above). If we cannot trust the person which is representing the whole company, we are implicitly losing trust of the whole organization. In cases like the Clinton - Lewinsky scandal, the question was not whether President Clinton lied to his wife about having an affair with young lady, but whether he lied to his nation about not having it (Denton-Holloway 2003). In the Deepwater Horizon oil spill (2010), the largest accidental marine oil spill in the petroleum industry, a severe damage on corporate reputation of British Petroleum was made by the CEO Tony Hayward, who went yachting soon after the catastrophe happened; this was understood as irresponsible and unconcerned behavior by the general public. ${ }^{6}$ In the Fukushima Case, when an earthquake, followed by a massive tsunami hit the coast of Japan's Island Honshú causing nearly 20,000 dead and damaging severely the Nuclear Plant in Fukushima, the loss of trust of the government was caused also by insufficient communication of the Prime Minister Naoto Kan and TEPCO ${ }^{7}$ representa-

6 Larry King Live. As the oil spill continues, BP CEO goes yachting. June 20th, 2010. Online. Jhttp://larrykinglive. blogs.cnn.com/2010/06/20/as-the-oil-spill-continues-bpceo-tony-hayward-goes-yachting/

7 Tokyo Electric Power Company, operating Nuclear plants incl. Fukushima
2012

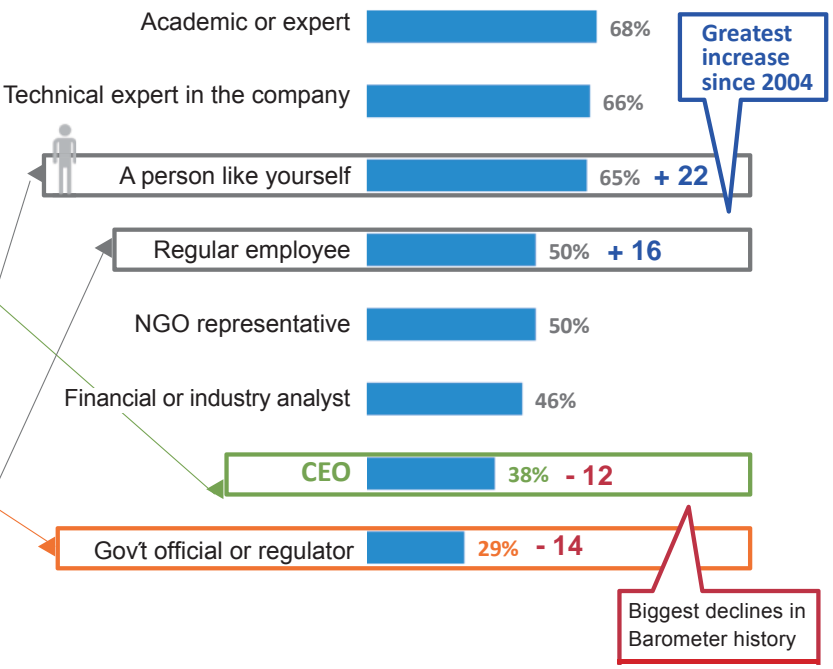

tives (especially soon after the disaster). As Ian Buruma writes in the case of TEPCO: "Worse still, few people had any understanding of who was responsible for what. (...) Prime Minister Naoto Kan had to ask TEPCO executives at one point, "What the hell is going on?" If Kan didn't know, how could anyone else?" (Buruma, 2011).

Globally, the trust of CEOs has fallen to the level of $38 \%$, the same as in 2009 soon after the Global Crisis started. Surprisingly in 2011, CEOs were seen as persons bringing credibility personally to the public - however the depth of decline (12\%), which is the biggest decline in one year in the history of this survey, shows us that the CEOs failed. The credibility of CEOs declined by $12 \%$ from 50 to $38 \%$ globally (see Graph 4 ) and in the EU only to $30 \%$ (see Graph 3). However, trust has to be present in business, so the rise of trust is more likely to happen with the overall recovery of the market.

In the past decade, the credibility of a CEO has played an important role in public relations and communication management. After 2001, we have seen the fall of so-called "celebrity CEOs", such as Dieter Zetsche, CEO of Chrysler, who was pictured on the cover of Businessweek in 20019, Carly Fiorina of Hewlett Packard or Jack Welch (General Electric). In 2005-2006, we can see the rise of "person-like-me" and peer credibility, which can be attributed as well to the rise of social

8 Source: EDELMAN. Edelman Trust Barometer: Global Results. New York, USA, 2012, January 23rd.

9 Bock, Wally (2001). Celebrity CEO's. Online. http://www. threestarleadership.com/articles/celebrity_ceos.htm 
media and personal blogs, in which some of them have become a stable part of our information sources as traditional media. Nowadays, we take Twitter, Facebook and personal blogs which we follow on the same level as other online sources - including versions of traditional media. The number of print media, including newspapers and economic magazines, is inevitably declining.

\section{Managerial Implications. CEOs need to change: be visible and plausible}

According to Graph 3 above, CEOs in the Czech Republic are still not very trusted - only by $38 \%$ of the informed public, which is the same level as in U.S. and $8 \%$ higher than in the E.U., yet less than in Slovakia (46\%). Interestingly, for Czech CEOs, trust is an essential line of their business - combined with transparent entrepreneurship. As opposed to global data, Czech CEOs do not see fair price, investor relations, innovations and CSR programs as being as important as their foreign colleagues do. ${ }^{10}$ In 2008, the credibility of institutions fell and people started turning their heads to the representatives and asking them for an explanation. However, CEOs "can't do magic". The disappointment arose mainly from the CEOs who were linked too closely to the economic bubble, yet were rewarded with high bonuses. In the Czech Republic, in 2011, the credibility of CEOs was generally higher (38\%), as many of the CEOs in the private sector gained a high reputation and opposed themselves to the governmental officials, the least trusted people worldwide. The personal PR of Radim Jančura, Student Agency and Regiojet CEO, is based delivering on quality services without state subsidies and a modest lifestyle, as opposed to České Dráhy CEO (Czech Railways, a state-operated company) Petr Žaluda, with a monopoly and the unfriendly image of Czech rails as well as a luxurious lifestyle as presented in glossy magazines.

In a conference PR Summit, concentrating on the credibility of CEOs in the Czech Republic, the most quoted "best practice" examples of credible CEOs were, apart from Radim Jančura also Stanislav Bernard, owner of Bernard brewery, Petr Kellner, owner of PPF company and member of Forbes top 100 billionaires list, Andrej Babiš from Agrofert company or Czech "Esteé Lauder" Eva Štěpánková or Ryor Company and others. All the

10 Source: Edelman Global Trust Barometer 2011, localized by survey among 25 Czech CEOs by affiliate agency AMI Communications. Data collected in September - October 2011. Presented in PR Summit Conference, October 19th, 2011. Kasl Kollmannová, D. (2011). The Influence of CEO on the Company's Reputation. Online. http://present. blueevents.eu/cs/default.aspx?pr=all\&btn=1\&cf=pr2011 above mentioned leaders have some common characteristics: they are known as the heads of their companies, no matter whether they are more visible in the media and advertising (Jančura, Bernard and Babiš) or keeping rather a low-profile (Kellner, Štěpánková). They offer transparent behavior or at least it is a part of their image and communication strategy. They are either socially active (Jančura and Babiš) or linked with CSR programs or green marketing (Kellner, Štěpánková). Despite their personal wealth, they do not show it ostentatiously and they are mostly trying to keep the image of strong leaders, yet "one-of-us".

The credibility of the CEO needs to be an integral part of the reputation management of the whole company. If the CEO fails like Tony Hayward in BP, it's clear that the reputation of the company will fall immediately, and then it might rise again. But if the $\mathrm{CEO}$ or country representative is reluctant to speak up with a clear idea and vision or take responsibility for actions, like Naoto Kan after the Japanese tsunami in 2011, trust will be damaged; in addition, the path to restore credibility might be even longer. The CEO's vision must be embodied in the management of the organization as well. As the influence of regular employees rises, Christopher Hannegan (Hannegan, 2012) recommends engaging the employees as core ambassadors of the company. Therefore, internal communication must get into the center of strategic communication. The $\mathrm{CEO}$ has to become a true leader not just as a celebrity, as we have experienced in 2001, but as an integral and present part of the organization. To see some best-practice example, the Czechs and Slovaks could also take a retrospective view and inspiration by Tomáš Bat'a, one of the first Czech entrepreneurs, which set the professional way of both internal and external communication.

\section{Conclusions}

This article showed the problem regarding the decline of trust in all types of organizations, commercial, non-profit and state institutions. In 2012, we have experienced an overall decrease of trust, especially in CEOs and state officials. On the other side, more trusted are peers and regular employees, who raise their voices through social, online and more and more also traditional media. Their opinion must be taken into account by CEOs and top management. Trust is easy to lose yet difficult to regain, so the path to be trusted again by the general public will be thorny. Management has to accommodate the changes and communicate transparently, often, on-time and understandably to both internal and external publics. The employees are the first ambassadors of the reputation of each company and their opinions are getting more attention. CEOs should not resign the goal to become strong 
leaders, hence should they increase the attention they give to the opinions of employees or individual critics. Also the image of "good will" represented by a non-ostentatious lifestyle, CSR programs or ethical marketing is becoming a more important part of the corporate communication. CEOs need to open up and speak publicly, or let the public know their opinions and goals clearly. The have to be known, yet not be celebrities. By communicating consistently, transparently and delivering quality products and services, they become plausible and credible.

\section{References}

\section{Literature:}

Anderson, D. \& Anderson, L.A. (2001). Beyond Change Management: Advanced Strategies for Today's Transformational Leaders. San Francisco: Jossey-Bass/Pfeiffer.

Bentele, G. - Nothhaft, H. (2011). Vertrauen und Glaubwürdigkeit als Grundlage von Corporate Social Responsibility: Die (massen-)mediale Konstruktion von Verantwortung und Verantwortlichkeit. In: Raupp, J. - Jarolimek, S. - Schultz, F. (2011). Handbuch CSR. Heidelberg: Springer. P. 45-70

Bentele, G., Seidenglanz, R. (2005). Vertrauen und Glaubwürdigkeit. In: Bentele, Günter/Romy Fröhlich/Peter Szyszka (Hrsg.)(2005): Handbuch der Public Relations. Wissenschaftliche Grundlagen und berufliches Handeln. Mit Lexikon. Verlag für Sozialwissenschaften, p. 346-360.

Clarke, S.H. (2007). Trust and Power: Consumers, the Modern Corporation and the making of the United States Automobile Market. Cambridge: Cambridge University Press

Denton, R.E. - Holloway, R. L. (eds.). (2003). Images, Scandals and Communication Strategies of the Clinton Presidency. Westport: Praeger Publishers.

Ferguson, N. (2009). The ascent of money. New York: Penguin.

Fukuyama, F. (1995). The Social Virtues and the Creation of Prosperity, New York: Free Press.

Hardin, R. (2002). Trust and Trustworthiness, New York: Russell Sage Foundation.

Hofstede, G. (2001). Culture's Consequences: comparing values, behaviors, institutions, and organizations across nations (2nd ed.). Thousand Oaks, CA: SAGE Publications.

James, H.S. Jr. (2002). The Trust Paradox: A Survey of Economic Inquiries into the Nature of Trust and Trustworthiness. Journal of Economic Behavior and Organization, 47(3): 291-311

Krugman, P. (2009). The Return of Depression Economics and the Crisis of 2008. New York: W.W. Books

Lehrer, K. (1997). Self-Trust: A Study of Reason, Knowledge, and Autonomy, New York: Oxford University Press.

Luhmann, N. (1979). Trust and Power, Toronto: Wiley.

Potter, N. N., 2002. How Can I be Trusted? A Virtue Theory of Trustworthiness, Lanham, Maryland: Rowman \& Littlefield.

Virilio, P. (2001). The Information Bomb. London: Verso

\section{Online Sources:}

AMI Communications. Češi jsou národem nevěřicich Tomášů. Press release. (Accessed May 14th, 2012), [available at http://www.amic.cz/vyzkum/trust-barometer-2012-kolikratmusi-lide-slyset-informaci-aby-ji-uverili/].

Edelman. Edelman Trust Barometer: Global Results. New York, USA, 2012, January 23rd. (accessed May 5th, 2012). [available at http://www.slideshare.net/ EdelmanInsights/2012-edelman-trust-barometer-globaldeck]

Hannegan, C. (2012). Building Trust From the Inside Out: Engaging Employees as the New Influencers. (accessed May 10th, 2012). [available at http://trust.edelman.com/ slides/building-trust-from-the-inside-out-engagingemployees-as-the-new-influencers/]

Kasl Kollmannová, D. (2011). The Influence of CEO on the Company's Reputation. PR Summit Conference, October 19th, 2011. (accessed May 20th, 2012), [available at http://present.blueevents.eu/cs/default. aspx?pr=all\&btn $=1 \& \mathrm{cf}=\mathrm{pr} 2011]$

Larry King Live. As the oil spill continues, $B P C E O$ goes yachting. June 20th, 2010. (accessed May 20th, 2012), [available at http://larrykinglive.blogs.cnn. com/2010/06/20/as-the-oil-spill-continues-bp-ceo-tonyhayward-goes-yachting/]

McLeod, C. (2011), „Trust“", The Stanford Encyclopedia of Philosophy (Spring 2011 Edition), Edward N. Zalta (ed.), (accessed May 20th, 2012), [available at http://plato. stanford.edu/archives/spr2011/entries/trust/>.]

Tseng, N.-H. (2012). Maybe Greece needs a run on the banks. Fortune. May 21st. (accessed May 24th, 2012), [available at http://finance.fortune.cnn.com/2012/05/21/ greece-bank-run/]

Zerfass, A., Verhoeven, P., Tench, R., Moreno, A., \& Verčič, D. (2011):European Communication Monitor 2011. Empirical Insights into Strategic Communication in Europe. Results of an Empirical Survey in 43 Countries (Chart Version). Brussels: EACD, EUPRERA, (accessed May 20th, 2012), [available at www.communicationmonitor.eu]

Bock, Wally (2001). Celebrity CEO's. (accessed May 20th, 2012), [available at http://www.threestarleadership.com/ articles/celebrity ceos.htm]

Buruma, I. (2011). Japan's Political Tremors, (accessed May 20th, 2012), [available at http://www.project-syndicate.org/ commentary/japan-s-political-tremors]

\section{Author}

PhDr. Denisa Kasl Kollmannová, Ph.D. Head of Department Marketing Communication and Public Relations Faculty of Social Sciences Charles University in Prague Smetanovo nábřeží 6, 11000 Praha 1 kollmannova@fsv.cuni.cz 